\title{
Histopathological, immunohistochemical and biomolecular diagnosis of myocarditis due to Clostridium chauvoei in a bovine
}

\author{
Diagnóstico anatomopatológico, imuno-histoquímico e biomolecular de \\ um caso de miocardite por Clostridium chauvoei em um bovino
}

\author{
Renata Assis Casagrande ${\text { Prhiscylla Sadanã Pires }{ }^{\mathrm{II}} \text { Rodrigo Otávio Silveira Silva }{ }^{\mathrm{I}}{ }^{\star}}$ \\ Luciana Sonne ${ }^{\mathrm{III}}$ João Batista Souza Borges ${ }^{\mathrm{III}}$ Monique Silva Neves ${ }^{\mathrm{II}}$ Veronica Machado Rolim ${ }^{\mathrm{III}}$ \\ Suyene Oltramari de Souza ${ }^{\text {III }}$ David Driemeier"II Francisco Carlos Faria Lobato ${ }^{\text {II }}$
}

\section{- NOTE -}

\begin{abstract}
The aim of this study was to report a case of clostridial myocarditis in a bovine in Brazil with emphasis on the pathological findings, isolation and molecular identification associated with the in situ localization of $\boldsymbol{C}$. chauvoei. The animal, a male Brangus bull with nine months of age, was found dead without prior clinical signs. Multifocal and coalescent areas of necrosis were observed in the myocardium. Rod cells in the cardiac muscle fibers were positive immunostaining for $\boldsymbol{C}$. chauvoei, while this bacterium was also isolated and identified by polymerase chain reaction (PCR).
\end{abstract}

Key words: myonecrosis, sudden death, Clostridium chauvoei, myocarditis.

\section{RESUMO}

O objetivo deste estudo foi relatar um caso de miocardite clostridial em um bovino no Brasil, com ênfase nos achados patológicos, isolamento e identificação molecular do agente e visualização in situ de $\boldsymbol{C}$. chauvoei. O animal, um macho da raça Brangus com nove meses de idade, foi encontrado morto sem sinais clínicos prévios. Foram observadas áreas de necrose multifocal e coalescente no miocárdio, com a presença de bastonetes imunomarcados para $\boldsymbol{C}$. chauvoei nas fibras musculares cardiacas. Uma estirpe de C. chauvoei foi isolada do tecido e sua identidade foi confirmada por reação em cadeia da polimeras (PCR).

Palavras-chave: mionecrose, morte súbita, Clostridium chauvoei, miocardite.

Blackleg is an endogenous infection that affects domestic ruminants and results from the activation of dormant spores of $\boldsymbol{C}$. chauvoei present in muscle (HATHEWAY, 1990). Although clostridia are a relatively well-studied group of bacteria, the pathogenesis of blackleg has not yet been fully elucidated. The dominant hypothesis suggests that $\boldsymbol{C}$. chauvoei is deposited into the muscle after transport by the bloodstream from the intestine, most likely by macrophages. A subsequent injury, such as a small intramuscular hemorrhage, could generate the anaerobic conditions needed for spore germination and the consequent production of toxins, culminating in the death of the animal (GYLES, 1993; UZAL, 2012).

There are two distinct forms of blackleg in cattle: a classical and visceral form, both of which are usually fatal (MALONE et al., 1986; UZAL et al., 2003; ASSIS et al., 2010). The classical myonecrosis is usually found in cattle up to 24 months old and is characterized by an acute neutrophil necrotizing myositis that mainly affects skeletal muscle. However, visceral myonecrosis is rarely diagnosed and can affect the heart, the sublingual muscles and the diaphragm (MALONE et al., 1986; UZAL et al., 2003; HARWOOD et al., 2007). In Brazil, the only report of visceral myonecrosis in cattle is a retrospective study that evaluated formalin-fixed tissues and diagnosed the disease using immunochemistry. In addition to the limitations of these evaluation methods, the authors of that study did not provide an accurate post mortem description and/or complete laboratory diagnosis (ASSIS et al., 2010). In light of this, the aim of this paper is to describe the pathological findings of

\footnotetext{
${ }^{\mathrm{I} C e n t r o ~ d e ~ C i e ̂ n c i a s ~ A g r o v e t e r i n a ́ r i a s ~(C A V), ~ U n i v e r s i d a d e ~ d o ~ E s t a d o ~ d e ~ S a n t a ~ C a t a r i n a ~(U D E S C), ~ C o n t a ~ D i n h e i r o, ~ L a g e s, ~ S C, ~ B r a s i l . ~}$

"Escola de Veterinária (EV), Universidade Federal de Minas Gerais (UFMG), Avenida Antônio Carlos, 6627, 31270-901, Belo Horizonte, MG, Brasil. E-mail: rodrigo.otaviosilva@gmail.com. "Corresponding author.

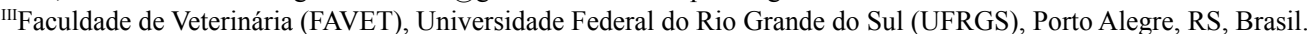


clostridial myocarditis in a bull followed by isolation and molecular identification of $\boldsymbol{C}$. chauvoei with an in situ localization.

A male Brangus bull, 9 months of age was referred to the Federal University of Rio Grande do Sul(UFRGS), where the necropsy was performed. The animal was found dead without prior clinical signs. The bovine belonged to a herd of 150 animals kept at a farm in the state of Rio Grande do Sul, Brazil, and had been vaccinated for foot and mouth disease in the week before death, but did not receive vaccines against any clostridia disease. All animals had been weaned 30 days before and were being kept in a native pasture, supplemented with corn feed produced on the farm.

Atnecropsy, a large amount of reddish liquid containing fibrin was observed in the thoracic cavity. In the heart, the pericardium was adhered to the parietal pleura and epicardium. Additionally, significant fibrin deposition (Figure 1A), marked dilatation of the right and left ventricles and multifocal areas of pallor measuring $0.5 \mathrm{~cm}$ were found in the myocardium (Figure 1B). The lungs were slightly collapsed and

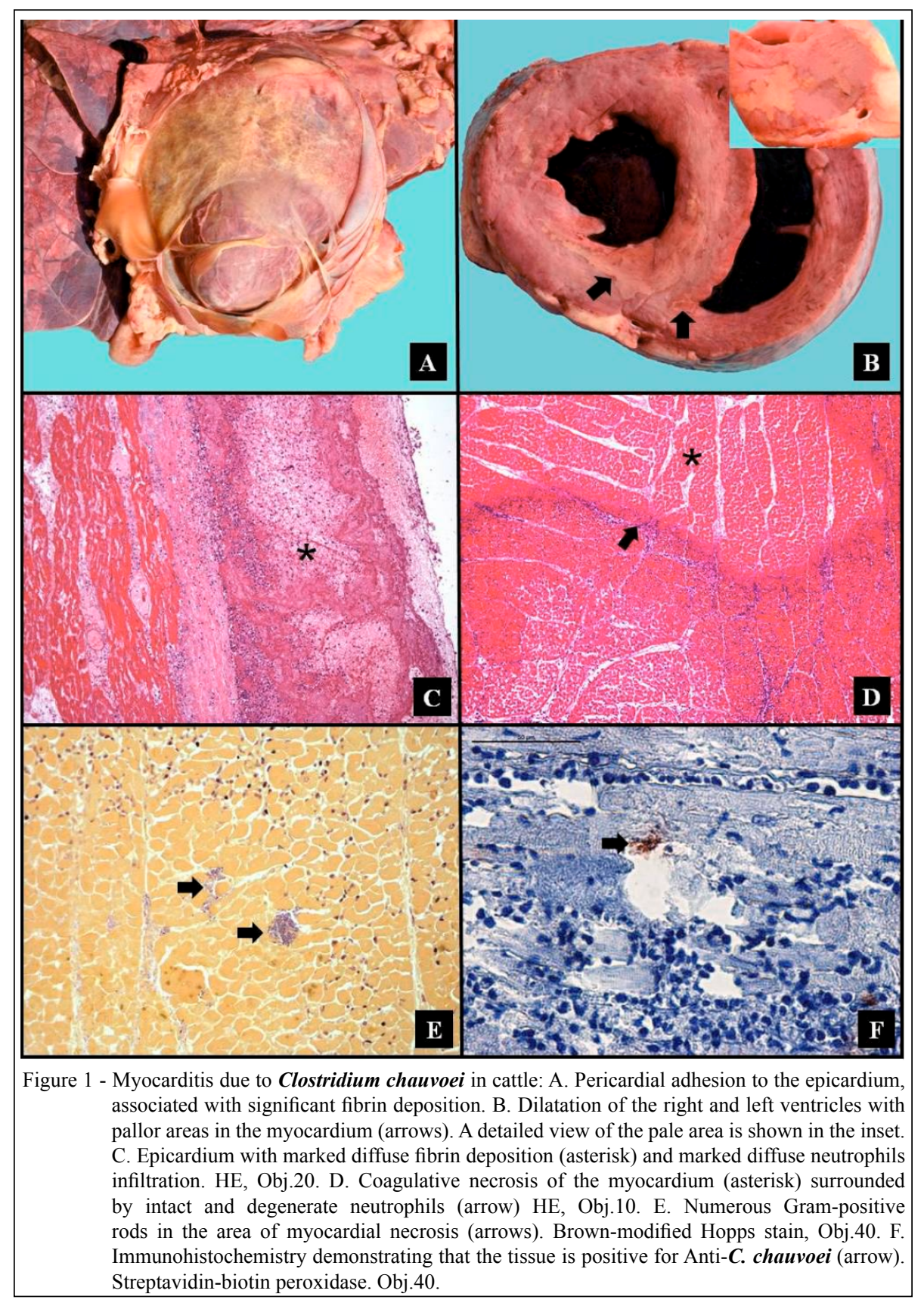

Ciência Rural, v.45, n.8, ago, 2015. 
reddish in color, and cutting into the tissue resulted in the extravasation of large amounts of a reddish liquid. Samples of the organs were collected, fixed in $10 \%$ buffered formalin, and processed routinely for histopathology and Gram staining. Additionally, tissue samples, frozen histological sections of the heart, and the liquid that was found in the pericardial sac were sent to the Escola de Vetrinária da Universidade Federal de Minas Gerais (UFMG) for immunohistochemistry (IHC), bacterial culture and etiological identification.

IHC was performed using antibodies against $\boldsymbol{C}$. chauvoei, $\boldsymbol{C}$. perfringens type A, $\boldsymbol{C}$. sordellii, $C$. novyi and $C$. septicum as previously described by PIRES et al. (2012). In addition, fractions of thawed samples were macerated with a sterile mortar and pestle in silica an inoculated onto Reinforced Clostridial Medium (RCM, Difco, USA) broth and Mueller Hinton (Difco, USA) agar supplemented with $5 \%$ defibrinated sheep blood. The fluid collected from the pericardial sac was directly inoculated onto the same culture media. Then, the samples were incubated in an aerobic atmosphere $\left(80 \% \mathrm{~N}_{2} ; 10 \% \mathrm{CO}_{2}\right.$ and $\left.10 \% \mathrm{H}_{2}\right)$ at $37^{\circ} \mathrm{C}$ for 48 hours. The colonies were subjected to morphological and colorimetric evaluation by Gram staining and evaluated by multiplex polymerase chain reaction (PCR) to detect $\boldsymbol{C}$. chauvoei, $\boldsymbol{C}$. perfringens type A, $C$. sordellii, $C$. novyi and $C$. septicum as described by RIBEIRO et al. (2012).

After anaerobic incubation, the RCM broth became turbid and rhizoid colonies with jagged edges and slight hemolytic activity were detected on the blood agar. The colorimetric characterization revealed the presence of short Gram-positive rods with centralized lemon-shaped spores, consistent with C. chauvoei (HATHEWAY, 1990), and this finding was confirmed by multiplex PCR.

On histopathological evaluation, there were multifocal to coalescing, large aggregates of fibrin within pericardium sac and epicardium, with a marked diffuse infiltration of neutrophils (Figure 1C), as well as mesothelial proliferation and blood vessels in the pericardial sac. Multifocal and coalescent areas of coagulative necrosis surrounded by intact and degenerate neutrophils, hemorrhage and fibrin deposition were observed in the myocardium (Figure 1D) in addition to thromboses in multiple vessels. In areas of pericarditis and myocarditis, numerous Grampositive rods were detected (Figure 1E). IHC revealed moderate amounts of rod cells that were diffusely distributed between cardiac muscle fibers with positive immunostaining only for C. chauvoei (Figure 1F), reinforcing the results obtained in the multiplex PCR. In the lungs was observed congestion and edema diffuse moderate secondary to cardiac damage.

Visceral blackleg should be considered a primary focus of infection when there are no associated skeletal injuries, as in this case. When musculoskeletal necrosis is evident, visceral lesions are considered a secondary consequence of the primary infection. In a study evaluating cases of myonecrosis caused by $\boldsymbol{C}$. chauvoei, MALONE et al. (1986) reported visceral myocarditis as the primary source of infection in $21 \%$ of cases. On the other hand, UZAL et al. (2003) evaluated an outbreak in which all animals had exclusively cardiac lesions associated with the presence of $\boldsymbol{C}$. chauvoei. In a retrospective study to evaluate 32 samples with clinical suspicion of myonecrosis, ASSIS et al. (2010) found $\boldsymbol{C}$. chauvoei as the sole etiologic agent in $21 \%$ of cases, although only $6 \%$ of cases presented with an infarction as the primary lesion.

Cardiac lesions associated with $\boldsymbol{C}$. chauvoei are a rare finding, and descriptions of these cases are essential for a better understanding blackleg and its characteristics. Despite the known importance of this disease for cattle, this is the first report to confirm the diagnosis of visceral infection by $\boldsymbol{C}$. chauvoei based on detection in situ by IHC in addition to isolation and identification of the microorganism by PCR. According to UZAL et al. (2003), germination of $\boldsymbol{C}$. chauvoei in the myocardium is commonly associated with stress during vaccination. Specifically, in the present report, the age of the affected animal (9 months) is consistent with other reports of clostridial myocarditis (MALONE et al., 1986; UZAL et al., 2003; ASSIS et al., 2010).

In the present study, the diagnosis of myocarditis caused by $\boldsymbol{C}$. chauvoei was based on pathological findings in addition to the isolation and molecular identification of the agent and immunospecific labeling. Comparatively, the macroscopic and microscopic lesions described here were similar to those described previously by MALONE et al. (1986) and relatively different from those described by UZAL et al. (2003), who reported a diffuse necro-hemorrhagic myocarditis not associated with fibrino-necrotic pleuritis.

Histological evaluation of the cardiac tissue revealed an acute neutrophilic myocarditis associated with degeneration, necrosis and hemorrhage of cardiac fibers, similar to a previously report by UZAL et al. (2003) on an outbreak of clostridial myocarditis in calves. According to VAN VLEET \& VALENTINE (2007), fibrinous pericarditis and clostridial pleuritis 
observed in cases of myocarditis can be attributed to hematogenous infection by $\boldsymbol{C}$. chauvoei. Pathological changes such as myocardial necrosis (hyaline degeneration and coagulative necrosis) are common findings in $\boldsymbol{C}$. chauvoei infection (PIRES et al., 2012) and can be attributed to the action of toxins produced by this pathogen, which appear to promote cellular damage by forming pores in the plasma membranes of infected cells (FREY et al., 2012).

The diagnosis of clostridial myonecrosis is based on the clinical history, anatomical and pathological findings and identification of the etiological agent involved, which can be accomplished through bacterial isolation, direct immunofluorescence or IHC. Unlike IHC, which is sufficient for diagnosis based on the in situ localization of the agent, isolation is not considered an essential step (UZAL et al., 2003). However, isolation followed by PCR or even direct PCR from the tissue could be a good option when sample was not well conserved with formalin (RIBEIRO et al., 2012). In addition, molecular identification by PCR will be critical in future epidemiological studies of the strains involved in this disease (HALM et al., 2010; RIBEIRO et al., 2012). This is the first reported diagnosis of visceral blackleg in Brazil with primary myocarditis caused by $\boldsymbol{C}$. chauvoei. In addition, this study described the pathological characteristics of this case and reported the isolation and molecular and immunological identification of the agent.

\section{REFERENCES}

ASSIS, R.A. et al. Mionecroses clostridiais bovinas. Arquivos do Instituto Biológico, v.77, p.331-334, 2010.

FREY, J. et al. Cytotoxin CctA, a major virulence factor of Clostridium chauvoei conferring protective immunity against myonecrosis. Vaccine, v.30, p.5500-5505, 2012. Available from: $<$ http://www.ncbi.nlm.nih.gov/pubmed/22749595>. Accessed: Out. 29, 2014. doi: 10.1016/j.vaccine.2012.06.050.
GYLES, C.L. Histotoxic clostridia. In GYLES, C.L.; THEON, C.O. Clostridia. 2.ed. Ames: Iowa State University, 1993. p.106-113.

HALM, A. et al. Novel real-time PCR assay for simultaneous detection and differentiation of Clostridium chauvoei and Clostridium septicum in clostridial myonecrosis. Journal of Clinical of Microbiology, v.48, p.1093-1098, 2010. Available from: $<$ http://www.ncbi.nlm.nih.gov/pubmed/20129968>. Accessed: Out. 29, 2014. doi: 10.1128/JCM.01975-09.

HARWOOD, D.G. et al. Outbreak of intestinal and lingual Clostridium chauvoei infection in two-year-old Friesian heifers. Veterinary Record, v.161, p.307-308, 2007. Available from: <http://www.ncbi. nlm.nih.gov/pubmed/17766810>. Accessed: Out. 29, 2014.

HATHEWAY, C.L. Toxigenic clostridia. Clinical Microbiology Reviews, v.3, p.66-98, 1990. Available from: $<$ http://cmr.asm.org/content/3/1/66.short $>$. Accessed: Out. 29, 2014. doi: 10.1128/CMR.3.1.66.

LOBATO, F.C.F. et al. Clostridioses dos animais de produção. Veterinária e Zootecnia, v.20, p.29-48, 2013.

MALONE, F.E. et al. Pathological changes in the pericardium and meninges of cattle associated with Clostridium chauvoei. Veterinary Record, v.118, p.151-152, 1986. Available from: <http://www.ncbi. nlm.nih.gov/pubmed/3952970>. Accessed: Out. 29, 2014.

PIRES, P.S. et al. Comparative analysis of lesions caused by histotoxic clostridia in experimentally induced myonecrosis. Semina: Ciências Agrárias, v.33, n.6, p.2337-2346, 2012. doi: 10.5433/1679-0359.2012v33n6p2337.

RIBEIRO, M.G. et al. Myonecrosis by Clostridium septicum in a dog, diagnosed by a new multiplex-PCR. Anaerobe, v.18, n.5, p.504-507, 2012. Available from: <http://www.ncbi.nlm.nih.gov/ pubmed/22975141>. Accessed: Out. 29, 2014.

UZAL F.A. et al. Outbreak of clostridial myocarditis in calves. Veterinary Record, v.152, p.134-136, 2003. Available from: <http:// www.ncbi.nlm.nih.gov/pubmed/12585599>. Accessed: Out. 29, 2014.

UZAL, F.A. Evidence-based medicine concerning efficacy of vaccination against Clostridium chauvoei infection in cattle. Veterinary Clinics of North America: Food Animal Practice, v.28, p.71-77, 2012. Available from: <http://www.ncbi.nlm.nih. gov/pubmed/22374118>. Accessed: Out. 29, 2014.

VAN VLEET, J.F.; VALENTINE, B.A. Muscle and tendon. In: MAXIE, M.G. (Ed.) JUBB, PALMER'S pathology of domestic animals. 5.ed. Toronto: Elsevier Saunders, 2007. p.185-279. 